\title{
LEI 12.796/13 E A OBRIGATORIEDADE NA EDUCAÇÃO INFANTIL
}

\author{
LEY 12.796/13 Y LA OBLIGACIÓN EN LA EDUCACIÓN INFANTIL
}

LAW 12,796/13 AND THE OBLIGATORINESS IN EARLY CHILDHOOD EDUCATION

\author{
Maria Cecília LUIZ ${ }^{1}$ \\ Rafaela MARCHETTI ${ }^{2}$
}

RESUMO: O objetivo deste artigo foi identificar as concepções e opiniões de profissionais da Educação Infantil (gestores, professoras, funcionárias), de escolas municipais de uma cidade do interior paulista, a respeito da Lei n. 12.796/13 - que trata acerca da obrigatoriedade escolar. $\mathrm{O}$ pano de fundo da investigação foi evidenciar questões a respeito do direito e da obrigatoriedade, com foco no ciclo das Políticas Públicas da Educação Infantil (EI). Conforme a pesquisa, a Lei n. 12.796/13 teve grande aceitação por parte dos profissionais da educação, sendo que alguns se manifestaram sobre o assunto, mesmo tendo pouco conhecimento e reflexão sobre as modificações na EI. Um grande marco foi o esclarecimento que tinham quanto à responsabilidade dos municípios em ofertar vagas para as crianças de 4 a 5 anos de idade.

PALAVRAS-CHAVE: Educação infantil. Concepção de profissionais da educação. Políticas públicas educacionais. Direito e obrigatoriedade escolar.

RESUMEN: El propósito de este artículo fue identificar las concepciones de niños profesionales de la educación (gestores, profesores, empleados), a las escuelas públicas en una ciudad en el estado de São Paulo y sus opiniones acerca de la Ley n. 13/12.796 - que se trata obligatoria a la escuela. El fondo de la investigación era resaltar las cuestiones de derecho y la obligación, con un enfoque en el ciclo de las políticas públicas de educación infantil. Según la investigación, la Ley n. 13/12.796 tuvo gran aceptación por parte de profesionales de la educación, y algunos expresaron sus opiniones sobre el tema, incluso con poco conocimiento y reflexión acerca de las modificaciones en educación infantil. Un hito importante fue la aclaración que había con respecto a la responsabilidad de los municipios para ofrecer lugares para niños de 4 a 5 años de edad.

PALABRAS CLAVE: Educación infantil. Concepción de profesionales de la educación. Políticas educativas públicas. Derecho y obligación.

ABSTRACT: The purpose of this article was to identify the conceptions of Early Childhood Education professionals (managers, teachers, employees), from public schools in a city in the

\footnotetext{
${ }^{1}$ Universidade Federal de São Carlos (UFSCar), São Carlos - SP - Brasil. Professora do Departamento de Educação e do programa de pós-graduação em Educação (PPGE/UFSCar). ORCID: https://orcid.org/0000-00015140-2753. E-mail: mceluiz@gmail.com.

${ }^{2}$ Universidade Federal de São Carlos (UFSCar), São Carlos - SP - Brasil. Doutoranda do programa de pósgraduação em Educação (PPGE/UFSCar). ORCID: https://orcid.org/0000-0002-4617-5186. E-mail: marchettirafaela@gmail.com.
} 
State of São Paulo, and their opinions about Law n. 12,796/13 - on educational obligatoriness. The background of the research was to highlight issues regarding rights and obligation, with a focus on the cycle of Public Policies of Early Childhood Education (ECE). According to the research, Law $n$. 12,796/13 had great acceptance on the part of education professionals, and some expressed their views on the subject, even with little knowledge and reflection on the modifications in ECE. A major milestone was the clarification they had regarding the responsibility of the municipalities to offer vacancies for children of 4 to 5 years of age.

KEYWORDS: Early childhood education. Conception of education professionals. Public educational policies. School right and obligatoriness.

\section{Introdução}

O objetivo deste artigo foi identificar as concepções e opiniões de profissionais da Educação Infantil (gestores, professoras, funcionárias), de escolas municipais de uma cidade do interior paulista, a respeito da Lei n. 12.796/13 - que trata acerca da obrigatoriedade escolar. O pano de fundo da investigação foi evidenciar questões a respeito do direito e da obrigatoriedade, com foco no ciclo das Políticas Públicas da Educação Infantil (EI). A temática é recorrente nas políticas públicas brasileiras, principalmente, no que se refere à escolarização da Educação Básica, do combate à mortalidade infantil e dos programas de proteção.

Nesse contexto, considera-se duas perspectivas importantes: a primeira, refere-se às diferentes concepções de infância e como foram caracterizadas em diferentes períodos da história e cultura. A segunda diz respeito a necessidade e a importância das políticas públicas de educação para a infância serem implementadas pelo Estado, compreendendo a criança como um sujeito de direitos sociais.

Para refletir sobre criança e infância, este estudo utiliza-se do conceito da Sociologia da Infância, em que as crianças são vistas como produtoras e transformadoras de culturas em seus contextos sociais e não somente sujeitos inseridos na sociedade (OLIVEIRA, 2008).

A criança é apercebida como parte de uma geração e participa das relações mútuas entre: crianças-adultos, crianças-crianças e crianças-sociedade. Entende-se, também, que ela deve ter garantidos os seus direitos nos diferentes âmbitos sociais, por isso para conceituá-la ou buscar reflexões sobre a EI é importante fundamentar-se nas políticas públicas educacionais e sociais.

Para Behring e Boschetti (2006), não existe uma data precisa de quando as políticas sociais para infância surgiram, mas acredita-se que a Revolução Industrial foi um marco importante. Neste período, em que a exploração do capital sobre o trabalho era muito forte, as políticas públicas e sociais constituíam-se remotas, assim como a pouca preocupação do Estado com a questão social. Segundo os autores (2006), as políticas sociais se ampliaram de maneira 
gradual em diferentes países - conforme as classes sociais - se intensificando apenas no final do século XIX, devido à ação do Estado capitalista.

Para Gonçalves (2010), as políticas públicas sociais têm como objetivo estabelecer um vínculo entre o Estado e a sociedade civil, por isso existe uma dimensão subjetiva nas suas formulações e execuções, visto que a própria noção de direitos sociais é subjetiva. As ideias de bem-estar individual e coletivo representam transformações, se apresentam como direitos sociais, conforme determinados períodos da história, com a aceitação de cada sociedade.

Segundo Filho (1982), o direito dos seres humanos elucida um ideal de justiça construído pelos sujeitos e transformado ao longo da história e das sociedades. A lei neste sentido se torna a racionalização humana capaz de permitir a criação de estruturas com a função de concretizar o direito. Assim, ao se promulgar uma lei - direito subjetivo de um sujeito ou grupo - o Estado fica responsável por garantir seu cumprimento, e a sociedade incumbida de exigir essa garantia por meio de ações e de políticas públicas criadas pelo governo (Poder Executivo). Pode-se dizer que é essa característica que retira o direito do papel para a realidade das relações no interior de uma sociedade.

A educação, diferentemente de outros direitos sociais, está vinculada ao direito e à obrigatoriedade, conforme Constituição Federal (CF) de 1988, em seus artigos 205 e 208. O direito a educação só se efetiva quando o seu reconhecimento jurídico está sendo conduzido pela vontade dos poderes públicos. Assim, o Estado pode garantir a educação (como lei), mas é o Poder Executivo (governo) que deve adotar políticas públicas com ações concretas para garantir a perspectiva educacional e a sociedade brasileira deve se organizar, reivindicando seus direitos perante a justiça.

O Estado, em conjunto com a sociedade, deve se incumbir de criar mecanismos que obriguem o governo e, consequentemente, os sujeitos a cumprirem os termos das legislações. Entende-se que os ciclos das Políticas Públicas representam o conjunto de ações realizadas pelo Poder Executivo, com garantia do Poder Legislativo (Estado), a fim de atender as demandas propostas pela sociedade civil, isto significa que estes momentos políticos devem acatar as legislações existentes, fazendo valer o direito e a obrigatoriedade para todos os cidadãos brasileiros. 


\section{Políticas públicas para Educação Infantil no Brasil}

Infelizmente, o reconhecimento de instituições de Educação Infantil como instituições capazes de fornecer uma boa educação só aparece a partir da década de 1960, com a expansão da força de trabalho feminino aos setores médios da sociedade. Na visão de Kuhlmann (2010), as creches originaram-se de influências de vários setores da sociedade, tais como: jurídicopolicial, religioso e médico-higienista. O setor jurídico-policial compreendia que o trabalhador era merecedor de ações beneficiárias devido a sua situação social, mas sem que isso o tornasse alguém detentor de direito. O setor religioso pregava seus dogmas às classes menos favorecidas, com intenção de fazê-las aceitar suas condições econômico-sociais, contribuindo para o seu controle. O setor médico-higienista se preocupava com os menos favorecidos nas questões de infraestrutura e planejamento urbano, com o objetivo de evitar doenças e grandes epidemias para toda sociedade. Para o autor (2010), as creches e os jardins de infância iniciaram seu processo de expansão no Brasil com caráter assistencialista e discriminatório. Os governantes ofereciam as creches para as classes sociais menos favorecidas como benefício e amparo. Sua vinculação aos órgãos governamentais de serviço social prorrogou esta concepção assistencialista por um longo período. Segundo Sousa, Pedroza e Sousa:

[...] tanto os países desenvolvidos quanto os subdesenvolvidos seguiam dois modelos institucionais, prioritariamente, sendo as creches destinadas exclusiva ou principalmente às crianças pobres, e os jardins de infância não destinados especialmente a estas. Havia uma segregação social e política, dependendo da classe econômica das pessoas (2014, p. 651).

Assim, as políticas públicas eram direcionadas à criação de creches junto às indústrias, bem como os congressos científicos indicavam a importância da regulamentação das relações de trabalho e o reconhecimento do trabalho feminino. A origem dessas instituições estava relacionada diretamente ao desenvolvimento da industrialização e da inserção da mulher no mercado de trabalho.

Somente a partir de 1980, as políticas públicas de educação brasileiras passaram a considerar a diversidade linguística e cultural nas práticas de educação (KRAMER, 2006). Miranda (2012) descreve que nas décadas 1970 e 1980, os movimentos sociais organizados colocaram a Educação Infantil em pauta nas suas reivindicações, principalmente, pela conscientização social de que, nesta etapa da vida, as crianças teriam que ter seus direitos garantidos.

Em São Paulo, no mesmo período, diferentemente das creches que foram concebidas como assistencialistas, surge uma escola anexada à Escola Normal Caetano de Campos 
nomeada de Jardim de Infância, com proposta educacional específica para a elite, e um currículo organizado com bases nas propostas de Froebel e dos Kindergarten (KUHLMANN, 1986). A demanda promoveu uma recaracterização das instituições de Educação Infantil, diminuindo as discrepâncias de escolas destinadas para ricos e pobres, de forma que a instituição da EI fosse vista como importante para todas as classes sociais.

A caracterização das Instituições de Educação Infantil como parte dos deveres do Estado com a Educação foi expressa na Constituição de 1988 (BRASIL, 1988), e foi resultado de muitas lutas pela implementação de creches e pré-escolas que respeitem os direitos das crianças e das famílias. O direito a educação é então entendido como parte integrante dos direitos que todo cidadão possui, e cabe ao Estado assegurar tais direitos.

Os artigos $3^{\circ}$ e $4^{\circ}$ do Estatuto (BRASIL, 2007), referem-se à proteção integral e enfatizam as responsabilidades da família e do Estado na garantia dos direitos.

Art. $3^{\circ}$ A criança e o adolescente gozam de todos os direitos fundamentais inerentes à pessoa humana, sem prejuízo da proteção integral de que trata esta Lei, assegurando-se lhes, por lei ou por outros meios todas as oportunidades e facilidades, a fim de lhes facultar o desenvolvimento físico, mental, moral, espiritual e social, em condições de liberdade e de dignidade.

Art. $4^{\circ}$ É dever da família, da comunidade, da sociedade em geral e do Poder Público assegurar, com absoluta prioridade, a efetivação dos direitos referentes à vida, à saúde, à alimentação, à educação, ao esporte, ao lazer, à profissionalização, à cultura, à dignidade, ao respeito, à liberdade e à convivência familiar e comunitária (BRASIL, 2007).

$\mathrm{O}$ artigo 53, dessa mesma lei, refere-se à educação dizendo como ela pode contribuir na construção da cidadania, na qualificação do trabalho e também destaca as condições para o acesso à escola pública. $\mathrm{O}$ artigo 54 trata sobre a obrigatoriedade do Estado no atendimento às crianças de zero a seis anos.

Art. 53. A criança e o adolescente têm direito à educação, visando ao pleno desenvolvimento de sua pessoa, preparo para o exercício da cidadania e qualificação para o trabalho, assegurando-se lhes:

I - igualdade de condições para o acesso e permanência na escola;

II - direito de ser respeitado por seus educadores;

III - direito de contestar critérios avaliativos, podendo recorrer às instâncias escolares superiores;

IV - direito de organização e participação em entidades estudantis;

$\mathrm{V}$ - acesso à escola pública e gratuita próxima de sua residência.

Art. 54. É dever do Estado assegurar à criança e ao adolescente:

I - ensino fundamental, obrigatório e gratuito, inclusive para os que a ele não tiveram acesso na idade própria;

II - progressiva extensão da obrigatoriedade e gratuidade ao ensino médio (BRASIL, 2007). 
A Lei de Diretrizes e Bases da Educação Nacional (LDB) n. 9.394 de 20 de dezembro (BRASIL, 1996) promulga que a Educação Infantil se insere como uma etapa da Educação Básica, juntamente com o Ensino Fundamental, considerada uma grande conquista, uma vez que esta passa a ser entendida como direito de toda criança. Para Campos (2002), o trabalho pedagógico com crianças de zero a seis anos teve reconhecimento e adquiriu uma dimensão mais ampla no sistema educacional, atendendo as especificidades da infância.

Além das Diretrizes, outras políticas públicas foram pensadas para a Educação Infantil, entre elas a Política de Educação Infantil no Brasil (BRASIL, 2009), lei que agrupa itens como: acessibilidade à Educação Infantil pelas crianças de zero a seis anos; participação dos profissionais da Educação na elaboração da proposta pedagógica; formação continuada; ampliação de recursos orçamentários e ampliação de infraestrutura. Tal documento tem embasamento nos princípios estabelecidos na Conferência Internacional de Jomtiem, ocorrida em 1990 na Tailândia, reunindo vários países do mundo. O Brasil teve papel importante nesse momento, pois ele subscreveu o documento referente à primeira infância, com o objetivo de expandir e melhorar os cuidados com as crianças, principalmente, as desfavorecidas.

O projeto de lei n. 8.035/10 (BRASIL, 2010), no âmbito da Educação Infantil, criou o Plano Nacional de Educação (PNE) - aprovado em junho de 2014, para vigorar de 2014-2024 - enviado pelo Governo Federal ao Congresso em 15 de dezembro de 2010. O PNE fixou a universalização da educação para as crianças de quatro a cinco anos de idade na Educação Infantil, e para as crianças de zero a três anos, com atendimento de $50 \%$ de toda a população até 2016 (BRASIL, 2014).

\section{Lei 12.796/13: obrigatoriedade educacional}

Rosemberg (2009) apresenta alguns apontamentos sobre projetos de leis que passaram na Câmara Nacional e no Senado sobre a obrigatoriedade da Educação Infantil. A autora explicita alguns itens referentes à Proposta de Emenda à Constituição (PEC) 277/08; sendo que esta não foi à primeira tentativa de tornar a Educação Infantil obrigatória. Em 2000 a senadora Heloisa Helena propôs a Proposta de Emenda à Constituição 40/2000, tratando da obrigatoriedade da Educação Infantil para as crianças de 0 a 6 anos. A autora (2009) também enfatiza outro documento, a Proposta de Emenda à Constituição 487/2002 feita por Leo Alcatra, então deputado, propondo a alteração no artigo 8 da Constituição Federal, dispondo sobre a obrigatoriedade da Educação Infantil para as crianças de 4 a 6 anos. Também faz algumas discussões sobre a Proposta de Emenda à Constituição 277/2008, ressaltando que esta não 
tratava sobre a obrigatoriedade da Educação dos quatro aos dezessete anos, a qual foi só posteriormente incorporada ao texto. Esta proposta tinha uma perspectiva de acontecer gradativamente, com a finalidade de acabar com a desvinculação das Receitas da União.

A partir de 2011, buscou-se aumentar os recursos financeiros aplicados em educação, o que é indicado também no PNE como a necessidade de estabelecer metas para aplicação de recursos públicos, como proporção do produto interno bruto. Essa Proposta de Emenda Constitucional deu subsídios para a elaboração da Emenda Constitucional n ${ }^{\circ}$ 59/2009 (BRASIL, 2009), modificando também a redação do artigo 208 da Constituição Federal:

Art. 208. O dever do Estado com a educação será efetivado mediante a garantia de:

I-Educação Básica obrigatória e gratuita dos 4 (quatro) aos 17 (dezessete) anos de idade, assegurada inclusive sua oferta gratuita para todos os que a ela não tiveram acesso na idade própria;

$[\ldots]$

IV- Educação Infantil, em creche e pré-escola às crianças até 5 (cinco) anos de idade;

Essa Emenda estabeleceu ainda que:

Art. 211. A União, os Estados, o Distrito Federal e os Municípios organizarão em regime de colaboração seus sistemas de ensino.

[...] $\S 4^{\circ} \mathrm{Na}$ organização de seus sistemas de ensino, a União, os Estados, o Distrito Federal e os Municípios definirão formas de colaboração, de modo a assegurar a universalização do ensino obrigatório.

Mediante as alterações feitas, e segundo Cury e Ferreira (2010), finalmente o ensino obrigatório não é mais o Fundamental, mas, sim, a Educação Básica - Educação Infantil na etapa da pré-escola, Ensino Fundamental e Médio - para aqueles que tenham de 4 a 17 anos, assegurando inclusive uma oferta gratuita para todos os que não tiveram acesso à Educação na idade própria. A aprovação da Emenda pelo congresso tornou compulsória a frequência escolar dos quatro aos dezessete anos de idade.

A mudança conferiu ao Brasil, assim como em outros países, um maior tempo de obrigatoriedade escolar. Mas, infelizmente, não foi consensual no campo educacional, de modo que a extensão da obrigatoriedade para a Educação Infantil gerou diferentes reações em especial por: especialistas, pesquisadores e militantes do campo de estudos e de ação política da Educação Infantil e os dirigentes da educação, sobretudo municipais.

$\mathrm{O}$ artigo $6^{\circ}$ da Emenda Constitucional refere-se ao que está disposto no Artigo 208, inciso I, “deverá ser implementado gradativamente até 2016, com o apoio técnico e financeiro da União". Esse fato também é assegurado no PNE, que estabelece vinte Metas com estratégias 
de ação, a fim de coordenar um Sistema Nacional de Educação. A Educação Infantil foi contemplada na Meta I, especificando que o atendimento escolar da população de 4 e 5 anos deve ser universalizada até 2016 e ampliada até 2020, isto é, a oferta de Educação Infantil deve atender cerca de $50 \%$ das crianças com até 3 anos.

Esse princípio, também, é reafirmado no documento base da Conferência Nacional de Educação (CONAE, 2014) por meio do texto referente ao eixo IV Qualidade da Educação: Democratização do Acesso, Permanência, Avaliação, Condições de Participação e Aprendizagem.

Segundo Cury e Ferreira (2010), com a emenda 59 (BRASIL, 2009) a Educação Infantil na etapa da pré-escola (quatro aos cinco anos de idade) passa a ser obrigatória. Desta forma, toda alteração proporcionada por essa emenda possibilitou uma ampliação do dever constitucional do Estado em relação à educação. Porém, essa obrigatoriedade não se refere a uma etapa de Ensino em específico, mas, sim, a uma faixa etária que vai dos quatro aos dezessete anos. Portanto, a criança deve ingressar na escola com quatro anos de idade, passar pelo ensino fundamental e permanecer na escola até os dezessete anos, independente da etapa em que estiver, seja no fundamental ou médio. Ou seja, a qualidade do ensino e da aprendizagem não se torna necessariamente efetiva, no sentindo que essa criança curse a etapa que lhe seja adequada para seu desenvolvimento.

De acordo com Campos (2010), houve pouca atenção para a mudança na definição da obrigatoriedade que a emenda despertou, visto que esta incluiu a redução dos recursos subtraídos pela Desvinculação das Receitas da União e dos recursos vinculados à manutenção e ao desenvolvimento do ensino, antiga demanda do setor educacional. Segundo esse entendimento, a emenda garantiria aos legisladores o mérito da iniciativa, com a justificativa de que os maiores recursos destinados à educação seriam bem utilizados.

Nesta perspectiva, de ressignificação da EI, refletiu-se sobre as políticas públicas elaboradas para esta etapa de ensino, e evidencia-se uma legislação que preconiza a obrigatoriedade da matrícula das crianças com quatro anos de idade: a Lei no 12.796 , de 4 de abril de 2013, que dispõe sobre a alteração de vários artigos da LDB, entre eles o artigo $4^{\circ}$ :

I - Educação Básica obrigatória e gratuita dos 4 (quatro) aos 17 (dezessete) anos de idade, organizada da seguinte forma: a) pré-escola; b) ensino fundamental; c) ensino médio; [...] (BRASIL, 2013).

A lei mencionada versa sobre a obrigatoriedade escolar para crianças de quatro anos de idade. Nesta mesma lei, faz-se ainda a alteração do artigo $6^{\circ}$ da LDB: "É dever dos pais ou responsáveis efetuar a matrícula das crianças na Educação Básica a partir dos 4 (quatro) anos 
de idade". A obrigatoriedade no acesso a EI e demais etapas sendo caracterizada como um direito público subjetivo.

Por meio dessa mudança a Educação passa a ser entendida como um direito e um dever da Administração Pública para com o cidadão. Para a efetivação das disposições alteradas na Constituição Federal de 1988, aprovou-se a Lei 12796/13, que altera a LDB nº 9.394 (BRASIL, 1996), e dispõe sobre a formação dos profissionais da educação e traz em seu texto alterações consubstanciais na Lei de diretrizes e Base Nacional, tais como:

Art. $1^{\circ}$

A Lei $\mathrm{n}^{\circ}$ 9.394, de 20 de dezembro de 1996, passa a vigorar com as seguintes alterações:

Art. $4^{\circ}$

I - Educação Básica obrigatória e gratuita dos 4 (quatro) aos 17 (dezessete) anos de idade, organizada da seguinte forma:

a) pré-escola;

b) ensino fundamental;

c) ensino médio;

II - Educação Infantil gratuita às crianças de até 5 (cinco) anos de idade (BRASIL, 2013).

A Lei n. 12.796/2013 significa uma alteração expressiva na LDB 9.394/96, visto que por meio da Emenda Constitucional no 59/09, amplia a obrigatoriedade da faixa etária de quatro a dezessetes anos de idade, determinando que o ano de 2016 fosse o prazo final para essa universalização. Aumentam-se atendimento e recursos financeiros, mas, infelizmente, sem incluir as creches. Além disso, a Base Nacional Curricular Comum - BNCC (BRASIL, 2018) inclui a EI, mas não reformula e integra esta etapa de ensino, também, fica para traz a reivindicação de uma melhor formação para os profissionais da Educação Infantil, que ministram aulas para crianças pequenas, e para os diretores responsáveis pela gestão nas escolas, local em que se atende às demandas da infância.

\section{Procedimentos metodológicos}

Para a realização da pesquisa foram escolhidas três escolas, levando em consideração sua localização geográfica. O município pesquisado possuía 36 unidades de Educação Infantil, atendendo uma demanda de 8.576 crianças matriculadas, tendo 1.774 crianças na lista de espera aguardando vaga. A cidade divide-se em seis regiões, conforme os bairros em que estão localizadas. Os nomes das escolas são fictícios e foram criados para manter em sigilo os nomes verdadeiros: uma primeira, a escola Patinho Feio está localizada na periferia; outra, a escola João e Maria está no centro; e uma terceira, a escola Os Três Porquinhos está na região norte. 
Foram realizadas entrevistas semiestruturadas com quatro participantes de cada escola, divididos da seguinte maneira: um gestor; duas professoras - uma lecionando na fase 4 (crianças com quatro anos de idade) e outra lecionando na fase 6 (crianças com seis anos de idade) com alunos sem ter cursado a fase 4 ; e uma funcionária.

O Quadro 1 apresenta a caracterização dos gestores participantes da pesquisa:

Quadro 1 - Identificação do segmento diretor

\begin{tabular}{|c|c|c|c|}
\hline & $\begin{array}{c}\text { Diretora } \\
\text { Patinho Feio }\end{array}$ & $\begin{array}{c}\text { Diretora } \\
\text { João e Maria }\end{array}$ & $\begin{array}{c}\text { Diretora } \\
\text { Os Três Porquinhos }\end{array}$ \\
\hline Sexo & Feminino & Feminino & Feminino \\
\hline Idade & 38 anos & 39 anos & 32 anos \\
\hline Formação & $\begin{array}{c}\text { Magistério } \\
\text { Pedagogia }\end{array}$ & $\begin{array}{c}\text { Educação Física, Pedagogia } \\
\text { com especialização em } \\
\text { Educação Especial }\end{array}$ & $\begin{array}{c}\text { Magistério, Pedagogia } \\
\text { Especializações: } \\
\text { Direito Educacional, } \\
\text { Psicopedagogia e Gestão } \\
\text { Escolar }\end{array}$ \\
\hline Participam de & Conselho Escolar, & Conselho Escolar & APM \\
algum Colegiado? & APM & $\begin{array}{c}\text { Conselho Escolar } \\
\text { APM }\end{array}$ \\
\hline Função/Cargo & $\begin{array}{c}\text { Professora de Educação } \\
\text { Infantil efetiva e está } \\
\text { como diretora desde 2013 }\end{array}$ & $\begin{array}{c}\text { Professora de Educação } \\
\text { Física efetiva e está como } \\
\text { diretora desde 2013 }\end{array}$ & $\begin{array}{c}\text { Professora de Educação } \\
\text { Infantil efetiva e está como } \\
\text { diretora desde 2013 }\end{array}$ \\
\hline Tempo de Serviço & 12 anos & 15 anos & anos \\
\hline
\end{tabular}

Fonte: Autoria própria.

O quadro 2, referente às professoras atuantes na fase 4:

Quadro 2 - Identificação do segmento das professoras de crianças na fase 4

\begin{tabular}{|c|c|c|c|}
\hline Sexo & $\begin{array}{c}\text { Professor (a) } \\
\text { Patinho Feio }\end{array}$ & $\begin{array}{c}\text { Professor (a) } \\
\text { João e Maria }\end{array}$ & $\begin{array}{c}\text { Professor(a) } \\
\text { Os Três Porquinhos }\end{array}$ \\
\hline Idade & Feminino & Feminino & Feminino \\
\hline Formação & $\begin{array}{c}\text { Pedagogia, Especialização } \\
\text { em Educação Infantil } \\
\text { Educação Especial }\end{array}$ & $\begin{array}{c}\text { Pedagogia } \\
\text { Especialização em } \\
\text { Educação Especial }\end{array}$ & $\begin{array}{c}\text { Magistério } \\
\text { Nutrição }\end{array}$ \\
\hline $\begin{array}{c}\text { Participam de } \\
\text { algum colegiado? }\end{array}$ & Não & APM & Não \\
\hline Função/Cargo & $\begin{array}{c}\text { Professora efetiva da } \\
\text { Educação Infantil }\end{array}$ & $\begin{array}{c}\text { Professora efetiva da } \\
\text { Educação Infantil }\end{array}$ & $\begin{array}{c}\text { Professora contratada por } \\
\text { tempo Determinado da } \\
\text { Educação Infantil }\end{array}$ \\
\hline Tempo de Serviço & 6 anos & 8 anos & 3 anos \\
\hline
\end{tabular}

Fonte: Autoria própria.

O critério de escolha das professoras da Fase 6 foi ter alunos(as) que começaram a frequentar a escola a partir dos 5 ou 6 anos de idade, sem passar pela Fase 4. O quadro 3, referese à caracterização das professoras atuantes na fase 6: 
Quadro 3 - Identificação do segmento das professoras de crianças na fase 6 (com alunos sem ter cursado a fase 4 )

\begin{tabular}{|c|c|c|c|}
\hline & $\begin{array}{c}\text { Professor (a) } \\
\text { Patinho Feio }\end{array}$ & $\begin{array}{c}\text { Professor (a) } \\
\text { João e Maria }\end{array}$ & $\begin{array}{c}\text { Professor(a) } \\
\text { Os Três Porquinhos }\end{array}$ \\
\hline Sexo & Feminino & Feminino & Feminino \\
\hline Idade & 34 anos & 28 anos & 31 anos \\
\hline \multirow{2}{*}{ Formação } & Magistério & Licenciatura em & Magistério \\
& Pedagogia, & Matemática \\
& Especialização em & Pedagogia & Esagogia \\
& Educação Infantil, & Especialização em & Educação Infantil, Gestão \\
& Gestão Educacional e & Educação Especial & Escolar e Psicopedagogia \\
& Psicopedagogia & Não & Não \\
\hline Participam de & Conselho Escolar & & Professor Efetivo da \\
algum Colegiado? & Educação Infantil \\
\hline Função/Cargo & Professor Efetivo da & Professor Efetivo da & Educação Infantil \\
\hline Tempo de Serviço & Educação Infantil & 1 ano & \\
\hline
\end{tabular}

Fonte: Autoria própria.

Com relação à caracterização do segmento de funcionárias, explica-se que o critério de seleção foi feito por cada diretora, de cada escola participante:

Quadro 4 - Identificação do segmento funcionária

\begin{tabular}{|c|c|c|c|}
\hline & $\begin{array}{c}\text { Funcionário (a) } \\
\text { Patinho Feio }\end{array}$ & $\begin{array}{c}\text { Funcionário (a) } \\
\text { João e Maria }\end{array}$ & $\begin{array}{c}\text { Funcionário (a) } \\
\text { Os Três Porquinhos }\end{array}$ \\
\hline Sexo & Feminino & Feminino & Feminino \\
\hline Idade & 36 anos & 50 anos & 25 anos \\
\hline Formação & $\begin{array}{c}\text { Ensino Fundamental II } \\
\text { Incompleto }\end{array}$ & Pedagogia & Pedagogia \\
\hline $\begin{array}{c}\text { Participam de } \\
\text { algum Colegiado? }\end{array}$ & Não & Conselho Escolar & Não \\
\hline Função/Cargo & $\begin{array}{c}\text { Serviços Gerais } \\
\text { Efetiva }\end{array}$ & $\begin{array}{c}\text { Servente/Merendeira } \\
\text { Efetiva }\end{array}$ & $\begin{array}{c}\text { Agente Educacional } \\
\text { Efetiva }\end{array}$ \\
\hline Tempo de Serviço & 15 anos & 6 anos & 1 ano e 8 meses \\
\hline
\end{tabular}

Fonte: Autoria própria.

Das três funcionárias, apenas uma era membro do Conselho Escolar. Quanto às funções dos participantes, podemos elencar: serviços gerais, servente/merendeira e agente educacional - todas eram efetivas em suas funções. O tempo de serviço na Rede Municipal variava de um ano a quinze anos.

\section{Políticas públicas para a Educação Infantil: direito e obrigatoriedade}

Entendemos que a Lei n. 12.796/13 (BRASIL, 2013) não surgiu por um acaso, até porque suas perspectivas estavam vinculadas a condições econômicas e sociais, ou seja, condicionada a possibilidade de haver recursos financeiros, administrativos, pedagógicos, etc., 
para ocorrer a obrigatoriedade, do ponto de vista social a escolarização estava atrelada a questão do direito de crianças ingressarem na EI a partir dos 4 anos de idade.

Segundo Moss (2011), o discurso global a respeito do acesso à Educação Infantil acontece devido a sua contribuição na satisfação de padrões normativos e na garantia de vantagem às crianças ao ingressarem na etapa obrigatória, na medida em elas estariam sendo favorecidas por meio de comportamentos e desenvolvimento educacional. Para o autor (MOSS, 2011), este discurso tem propiciado a ação de formuladores de política em vários países e foi estabelecido a partir da relação com a educação obrigatória.

Destaca-se que ao perguntarmos para aos profissionais da educação sobre legislações vigentes, vários segmentos das diferentes escolas revelaram não ter conhecimento sobre a Lei 12.796/13, bem como outras ligadas a essa etapa de ensino. Segundo a diretora da escola Patinho Feio:

Então... Até o momento eu não sabia. Só sabia por conta da mídia, mas nunca li, nunca peguei pra ler, estou conhecendo agora (Diretora da escola Patinho feio, grifos nossos, 2014).

A professora da Fase 4 da escola João e Maria comentou não ter muito conhecimento sobre leis, apesar de ter relembrado que quando estudou tinha mais acesso e conhecimento sobre legislação, mas, não se recordava:

Estou meio desatualizada [...] eu estudei, mas, [...] eu sei da obrigatoriedade $\boldsymbol{e}$ tudo, mas, o nome de lei, essas coisas... Eu já esqueci muita coisa (Professora da Fase 4 da escola João e Maria, grifos nossos, 2014).

Infelizmente, o cumprimento das metas de acesso à Educação Infantil em resposta à legislação educacional é apenas um de tantos outros. Sabemos que questões como: a formação em nível superior dos professores, a organização dos espaços físicos que atendem as crianças (muitas vezes, bastante inadequados), a dificuldade dos sistemas municipais de ensino em definirem uma política curricular formada a partir das Diretrizes Curriculares Nacionais para a Educação Infantil, entre outros, estão na pauta das dificuldades de quem está responsável pelas instituições infantis.

Outro ponto importante foi anunciado pela funcionária da escola "Os três porquinhos" que apesar de conhecer a Lei, criticou a falta de discussões acerca da sua implementação:

Bom, eu sei que tem esta obrigatoriedade, e que ela vai levar esta criança agora pra escola, e até 2016, que me parece que é o prazo. Assim como a de nove anos, ela foi uma lei jogada, ela foi pensada, ela foi colocada em questão, mas assim, ela simplesmente surgiu. Eu, por exemplo, vi em um site de notícias, dia 5 de abril. Um dia depois, que ela foi promulgada, e

RPGE- Revista on line de Política e Gestão Educacional, Araraquara, v. 24, n. 1, p. 4-23, jan./abr., 2020. e-ISSN:1519-9029. 
simplesmente foi jogada. Não vi anteriormente discussões, e congressos e... Sei lá... Trabalhos que pudessem fazer eventualmente uma pesquisa pra ver se isso era possível, se cabia dentro de uma legislação brasileira, dentro dos próprios grandes documentos, para que tudo isso fosse possivel (Funcionária da escola Os três porquinhos, grifos nossos, 2014).

Rosemberg (2009) descreve que a adoção da obrigatoriedade na educação foi incorporada a Proposta de Emenda à Constituição 277/08 referente ao fim gradativo do mecanismo da desvinculação das Receitas da União, assim a educação obrigatória dos quatro aos dezessete anos não possuía uma proposta específica com objetivos definidos. Ressalta-se que não houve divulgação e debates sobre essas questões tão importantes para a EI.

Para os profissionais da educação que indicaram ter conhecimento sobre as legislações em geral, como a LDB, escutamos da mesma diretora:

Só a LDB. O que ela garante? Acho que ela não garante... Ela assegura? No meu ponto de vista ela assegura que a criança possa vir à escola (Diretora da escola Patinho Feio, grifos nossos, 2014).

A professora da Fase 4 tinha conhecimentos sobre a LDB:

[...] Agora eu não sei se isso é uma formalidade, uma lei que garante isso para crianças a partir de seis meses o ensino, um local pra ficar, um ensino gratuito, agora com essa nova lei com a obrigatoriedade dos quatro anos, o município tem que oferecer creche para criança a partir dos seis meses. $O$ município é obrigado a dar isso, esse serviço (Professora da Fase 4 da escola Patinho Feio, grifos nossos, 2014).

Em sua alocução, aparecem algumas dúvidas e o desconhecimento sobre a questão da oferta de vagas na Educação Infantil. A obrigatoriedade vem se estendendo, abarcando a Educação Infantil, por isso é importante afirmar que o ingresso da criança de zero a três anos é facultativo, mas é obrigação do município oferecer esse atendimento.

Com a Constituição Federal de 1988 (BRASIL, 1988), se estipulou o sistema educacional básico dever do Estado, de forma integrada e resinificada, dando à criança direitos. A diretora da escola João e Maria nos pareceu conhecer determinadas leis que especificam a quantidade de alunos por sala de aula, por exemplo, como o PNE e, também, a Resolução do Conselho Municipal de Educação nº 002/2006:

Sim, as leis, no caso, quantidade de alunos, obrigatoriedade, o que se deve o que não se deve fazer (Diretora da escola João e Maria, 2014).

A professora da Fase 4 da escola Patinho Feio declara que a obrigatoriedade foi promulgada por Lei Federal, mas o dever é do município: 
Então, o que eu soube agora é que as crianças a partir de quatro anos são obrigadas a serem inseridas no ambiente escolar, e isso é por parte do município? O município que tem de oferecer, não é do estado, nem federal. E, como a Educação Infantil é municipalizada, é o município que tem que oferecer, mas essa é uma lei federal, que eu sei (Professora da Fase 4 da escola Patinho Feio, grifos nossos, 2014).

Está especificado na LDB (BRASIL, 1996) que os municípios são responsáveis pela Educação Infantil, no que compete às escolas: corpo docente, material pedagógico, alimentação, entre outros:

Art. 11

V - oferecer a Educação Infantil em creches e pré-escolas, e, com prioridade, o ensino fundamental permitido a atuação em outros níveis de ensino somente quando estiverem atendidas plenamente as necessidades de sua área de competência e com recursos acima dos percentuais mínimos vinculados pela Constituição Federal à manutenção e desenvolvimento do ensino (BRASIL, 1996).

A professora suscita uma questão importante, uma vez que a Lei pode ser promulgada pelo governo federal, mas fará parte da realidade dos municípios brasileiros, mesmo que estes tenham situações muito diversificadas.

A funcionária da escola João e Maria, assim como a professora da Fase 4 da escola Patinho Feio, citaram que a legislação compete ao município:

Lembrar bem assim, eu não lembro as Leis. Eu conheço o que é Educação Infantil. Ela é responsabilidade do município (Funcionária da escola João e Maria, grifos nossos, 2014).

A Professora da Fase 6 da escola João e Maria afirma a importância da Educação Infantil e do Sistema Municipal em cumprir essa obrigatoriedade:

[...] a Lei foi posta porque é fundamental o ensino na Educação Infantil que é a base de tudo, e é através dele que se têm as regras. A família tem obrigação de matricular o aluno na rede, não importa qual seja, mas na Rede Municipal. Eu acho que é importante. Sem ela, como eu já falei, a defasagem estaria muito grande, já está, mas estaria muito pior! (Professora da Fase 6 da escola João e Maria, grifos nossos, 2014).

Essa professora acredita que o ensino e aprendizagem das crianças estejam defasados e, se não for realizado um trabalho educativo nas Redes Municipais agravaria a situação ainda mais. Esta polêmica nos faz refletir sobre a EI, que hoje, mesmo estando incluída na Educação Básica, não atende as metas da LDB em seu art. 62, que trata da formação inicial dos docentes - deveriam concluir o nível superior para atender às crianças da EB. Ao contrário, possui uma realidade preocupante em que se admite uma formação mínima em nível médio, na modalidade 
Normal. De acordo com a Sinopse do Professor, publicada pelo INEP ${ }^{3}$, existem quase 370 mil professores(as) atuantes na EI com apenas Ensino Fundamental e apenas cerca de 50\% deles tem o Ensino Superior completo.

Cumprir as metas de acesso à EI postas pela legislação educacional, bem como pelo PNE (2014-2020), deve exigir um esforço e empenho dos governos municipais, e um trabalho integrado entre governos estadual e Federal. O Programa Nacional de Reestruturação e Aquisição de Equipamentos para a Rede Escolar Pública de EI (ProInfância), criado em 2007, tinha como objetivo promover ações do Plano de Desenvolvimento da Educação (PDE), gerindo assistência financeira do governo federal, com metas de ampliar as vagas e o acesso à EI. Para a diretora da escola Patinho Feio nada de significativo mudou com a Lei, "pois os pais já colocavam seus filhos com quatro anos de idade na escola", alguns por medo do conselho tutelar do município e outros para não ter perda do benefício do Programa Bolsa Família:

Eu acredito que não, eu acho necessário, mas os pais já colocavam as crianças, né? Eu acho, então, que eles já achavam que era obrigatório, a partir dos quatro anos de idade. Acho que, se antes já tinham muitas crianças, agora só tende a aumentar, porque agora é obrigatório e os pais ficam com medo do Conselho Tutelar (Diretora da escola Patinho Feio, grifos nossos, 2014).

A diretora da escola João e Maria considerou que a Lei n. 12.796/13 foi elaborada e promulgada com intenções políticas. Assim, os pais seriam "obrigados a matricular as crianças", sendo beneficiados. Para ela, a educação é um benefício, ou uma caridade, e não, efetivamente, um direito:

É uma lei que simplesmente foi colocada para... (...) não sei se tem envolvimento político aí. Para tirar as crianças da rua, porque muitas mães deixam as crianças na rua e têm também aquelas parcerias com bolsa família, bolsa leite, bolsa tudo. (...) E aí acaba forçando os pais a manter os filhos na escola pra garantir o recebimento, alias o recebimento dessas bolsas, ele passa a ser a garantia de que a criança está sendo bem cuidada e protegida dentro do ambiente escolar (Diretora da escola João e Maria, grifos nossos, 2014).

Além disso, duas delas ainda tinham uma visão assistencialista, quando destacaram a importância de a criança estar protegida e bem cuidada no ambiente escolar. As professoras da Fase 4 e da Fase 6 da escola Patinho Feio expõem suas opiniões sobre a importância dessa Lei para as crianças:

${ }^{3}$ INEP - Sinopse do Professor 2009, atualizado em 17/12/2012. 
Eu acho que ela é importante, porque a visão de alguns pais. Às vezes, eles não têm muito acesso a informações, eu acho que eles pensam que a criança nessa idade não precisa de escola ainda. Ela só precisa estar na escola no primeiro ano, que seria hoje a criança de 7 anos, 6 anos né? Eu não concordo, eu acho que a criança com quatro anos ela já vai se desenvolver muito então a obrigatoriedade faz com que ela esteja de fato efetivamente inserida no ambiente escolar. (Professora da Fase 4 da escola Patinho Feio, grifos nossos, 2014).

Eu acho que é importante não só as crianças, mas os pais acordarem e sentir que a criança, para ter um futuro legal tem que entrar na escola mais cedo, e não ficar nas ruas. Porque eu vejo aqui na região que eu trabalho, crianças na rua, crianças tendo influências negativas, então a escola passa a ter esta parte positiva, e eu acho importante a criança entrar não só com 4 anos, mas entrar antes, eu acho legal (Professora da Fase 6 da escola Patinho Feio, grifos nossos, 2014).

As professoras concluem que essa Lei obriga os familiares a matricularem seus filhos na Educação Infantil a partir dos quatro anos de idade. O direito a educação torna-se nesse sentido uma obrigação. Como descreve Duarte (2004), sobre o direito público subjetivo, definido como uma capacidade reconhecida ao sujeito, devido à sua participação e expressão dos seus interesses.

Segundo Cury (2000), a escola é uma instituição de serviço público e se diferencia por oferecer ensino como bem público, assim, a gestão democrática é, antes de tudo, uma abertura ao diálogo e à democratização. Os colegiados que existem nas escolas devem ser representativos, com foco na representatividade da sociedade civil, portanto, podem definir normas e ações em suas esferas de atuação. Apesar de ser um desafio, buscam a garantia da institucionalidade, a favor dos direitos de todos, evitando priorizar vontades individuais de governos transitórios.

Muitas são as questões que ainda estão em aberto e, pior, elas não estão sendo debatidas nem com os profissionais da área e, muito menos, com a sociedade, em espaços democráticos que permitiriam oportunidade a ambas as partes falarem e ouvirem, com vistas a tomar decisões coletivas, com corresponsabilidade de todos.

\section{Considerações finais}

Este texto buscou refletir sobre várias questões que abarcam a EI, no que se refere às Políticas Públicas; legislações educacionais; etc. Além disso, identificou as concepções de profissionais de escolas municipais de um município paulista, a respeito da lei n. 12.796/13 e a obrigatoriedade escolar. Conforme legislação, a criança a partir de 4 anos de idade deve estar 
na Educação Infantil, cabendo às famílias matriculá-las e se responsabilizarem pela sua frequência na escola.

Todas as discussões referentes ao direito à educação estão intimamente ligadas com a obrigatoriedade escolar visto que, diferentemente de outros direitos sociais, ela está vinculada ao direito e a obrigatoriedade, conforme Constituição Federal de 1988, em seus artigos 205 e 208. Refletir sobre o direito à educação, na perspectiva de hoje, inclui também saber o significado de concepções estabelecidas pelas Políticas Públicas como: a universalização da educação com gratuidade, isto é, o acesso e a permanência na educação e a obrigatoriedade escolar, que estão imbricadas em necessidades e posicionamentos vindos da sociedade.

No Brasil, tais distinções são importantes e devem ser levadas em consideração, principalmente, no que se refere à elaboração e promulgação da Lei n. 12.796/13, que teve início onze anos antes com a Proposta de Emenda Constitucional - PEC 487/02 - que trata da obrigatoriedade das crianças de 4 a 6 anos de idade na Constituição Federal -, e que teve continuidade depois de seis anos com a PEC 277/08 - que trouxe a obrigatoriedade das crianças de 4 a 6 anos de idade na LDB 9394/96 -; momentos estes decisivos para ocorrer a alteração na Constituição em 2009, n 59/09 no artigo 208, e finalmente em 2013, na Lei n. 12.796/13 a alteração da LDB no artigo $4^{\circ}$.

Conforme a pesquisa, a Lei n. 12.796/13 teve grande aceitação por parte dos profissionais da educação, sendo que alguns se manifestaram sobre o assunto, mesmo tendo pouco conhecimento e reflexão sobre as modificações na EI. O distinto em seus relatos foi o esclarecimento quanto a responsabilidade dos municípios em ofertar vagas para as crianças de 4 a 5 anos de idade. Este encargo está no art. 11 da LDB (BRASIL, 1996), que estabelece a obrigação dos municípios em relação às suas esferas educacionais, priorizando a EI, assim como promulga que os recursos destinados à educação devem atender prioritariamente a este nível de ensino. Estas, e outras questões, ainda estão sem soluções, pois necessitamos de espaços democráticos na escola e na sociedade que permitam um posicionamento dos cidadãos com corresponsabilidade.

\section{REFERÊNCIAS}

BEHRING, E. R.; BOSCHETTI, I. Política social: fundamentos e história. São Paulo: Cortez, 2006.

BRASIL. Constituição da República Federativa do Brasil, de 5 de outubro de 1988. Diário Oficial da União, Brasília, 05 de outubro de 1988. Disponível em: 
http://www.planalto.gov.br/ccivil_03/Constituicao/Constitui\%C3\%A7ao.htm. Acesso em 15 jan. 2014.

BRASIL. Presidência da República. Lei n. 9394 de 20 de dezembro de 1996. Estabelece as Diretrizes e Bases da Educação Nacional. Diário Oficial da União, Brasília, 20 dez. 1996. Disponível em: http://www.planalto.gov.br/ccivil_03/LEIS/19394.htm. Acesso em: 10 mar. 2014.

BRASIL. Lei n. 11.274 de 6 de fevereiro de 2006. Diário Oficial da União, Brasília, DF, 7 fev. 2006. Disponível em: http://www.planalto.gov.br/ccivil_03/_Ato20042006/2006/Lei/L11274.htm. Acesso em 1 jun. 2014.

BRASIL. Estatuto da Criança e do Adolescente. 15 ed. São Paulo: Saraiva, 2007.

BRASIL. Emenda constitucional $n^{\circ} 59$ de 11 de novembro de 2009. Diário Oficial da União, Brasília, DF, 12 nov. 2009. Disponível em:

http://www.planalto.gov.br/ccivil_03/constituicao/Emendas/Emc/emc59.htm. Acesso em 1.abr. 2014

BRASIL. Ministério da Educação. Conselho Nacional de Educação. Câmara da Educação Básica. Revisão das Diretrizes Curriculares Nacionais para a Educação Infantil. PARECER CNE/CEB no: 20/2009. Brasília. DF. 2009.

BRASIL, Lei n. 13.005 de 25 de junho de 2014. Aprova o Plano Nacional de Educação. Diário Oficial da União, Brasília, DF, 26 jun. 2014. Disponível em:

http://www.planalto.gov.br/ccivil_03/_ato2011-2014/2014/lei/113005.htm. Acesso em: 26 de junho 2014.

BRASIL. Congresso Nacional. Processos legislativos da Lei n. 12.796, de 4 de abril de 2013. Disponível em: www.senado.gov.br e www.camara.gov.br. Acesso em: 2 abr. 2014.

BRASIL. Base Nacional Comum Curricular. Brasília: MEC. Versão entregue ao CNE em 03 de abril de 2018. Disponível em: http://basenacionalcomum.mec.gov.br/wpcontent/uploads/2018/04/BNCC. Acesso em: 04 abr. 2019.

CAMPOS, M. M. A legislação, as políticas nacionais de Educação Infantil e a realidade: desencontros e desafios. In: MACHADO, Maria Lúcia de A. (Org.) Encontros e desencontros em Educação Infantil. S P: Cortez, p. 27-34, 2002.

CURY, C. R. J. Legislação Educacional Brasileira. Rio de Janeiro: DP\&A, 2000.

CURY, J. R. C; FERREIRA, L.A. M. Obrigatoriedade da Educação das Crianças e Adolescentes: Uma questão de oferta ou efetivo atendimento? Nuances: Estudos sobre Educação. Ano XVII, v. 17, n.18, p. 124-145, jan./dez. 2010.

DUARTE, C. S. Direito público subjetivo e políticas educacionais. São Paulo. Perspectiva, vol. 18, n. 2. abr./jun. 2004.

FILHO, R. L. O que é direito? 11. ed. São Paulo. Editora Brasiliense, 1982. 
GONÇALVES, M.G. M. Psicologia, Subjetividade e Políticas Públicas. São Paulo: Cortez, 2010.

KRAMER, S. (org.). Com a pré-escola nas mãos: uma alternativa curricular para a Educação Infantil. São Paulo: Ática, 1991.

KRAMER, S. As crianças de 0 a 6 anos nas políticas educacionais no Brasil: Educação Infantil e/é fundamental. Educação e Sociedade, Campinas, v. 27, n. 96, p. 797-818, out. 2006.

KUHLMANN, J. M. Infância e Educação Infantil: uma abordagem histórica. $5^{\text {a }}$ edição. Porto Alegre: Mediação, 2010.

LOCKE, J. Ensaio Acerca do Entendimento Humano. Trad. Anoar Aiex. São Paulo: Editora Abril, 1978.

MIRANDA, P. R. Políticas Públicas para a Educação Infantil no Brasil 1 (1990-2001). Rev. Teoria e Prática da Educação, v. 15, n. 2, p. 175-177, maio/ago. 2012.

MOSS, P. Qual o futuro da relação entre Educação Infantil e ensino obrigatório? Cadernos de Pesquisa. v. 41, n. 142, jan./abr. 2011.

OLIVEIRA, F. A criança e a infância nos documentos da ONU: a produção da criança como 'portadora de direitos' e a infância como 'capital humano do futuro'. Orientadora: Anete Abramowicz. 2008. 173 f. Tese (Doutorado em Ciências Humanas) - Universidade Federal de São Carlos, São Carlos, 2008. Disponível em: https://repositorio.ufscar.br/handle/ufscar/2206. Acesso em 6 mar. 2020.

ONU. Declaração Universal dos Direitos Humanos. 1948. Disponível em: http://www.onubrasil.org.br/documentos/. Acesso em: 1.mar.2014.

ONU. Declaração Universal dos Direitos da Criança. 1959. Disponível em: http://www.dhnet.org.br/direitos/sip/onu/c_a/lex41.htm. Acesso em: 1 mar. 2014

ONU. Assembleia Geral das Nações Unidas. Convenção das Nações Unidas sobre os Direitos da Criança. 1989. Disponível em: http://www.onubrasil.org.br/documentos/. Acesso em: 1 mar. 2014.

PIAGET, J. A equilibração das estruturas cognitivas. Rio de Janeiro: Zahar, 1975.

ROSEMBERG, F. A educação pré-escolar obrigatória: versão preliminar. In: Reunião Anual da Anped, Caxambu/ MG, 2009. (Trabalho encomendado pelo grupo de Trabalho Educação de Crianças de 0 a 6 anos).

SOUSA, T. R.; PEDROZA, R. L. S.; SOUSA, J. V. A infância em foco: Estado, políticas públicas e educação. Revista Linhas Críticas, Brasília, DF, v. 20, n. 43, p. 643-663, set./dez. 2014. 


\section{Como referenciar este artigo}

LUIZ Maria Cecília; MARCHETTI, Rafaela. Lei 12.796/13 e a obrigatoriedade na Educação Infantil. Revista on line de Política e Gestão Educacional, Araraquara, v. 24, n. 1, p. 4-23, jan./abr., 2020. e-ISSN:1519-9029. DOI: https://doi.org/10.22633/rpge.v24i1.12750

Submetido em: 30/06/2019

Revisões requeridas: $25 / 08 / 2019$

Aprovado em: 30/11/2019

Publicado em: 06/01/2020 